\title{
A New Normal or Business-as-Usual? Lessons for COVID-19 from Financial Crises in East and Southeast Asia
}

\author{
O. Fiona Yap ${ }^{1}$ (1)
}

Accepted: 16 October 2020 / Published online: 27 October 2020

(c) European Association of Development Research and Training Institutes (EADI) 2020

\begin{abstract}
Crises and dislocations home in on social, economic, and political weaknesses that are often sidestepped or pushed to the backburner in the interests of master plans of growth or development. Recovery from crises, then, provides the opportunity to address these underlying issues that preceded and, likely, contributed to the crises or dislocation; meanwhile, a return to the previous normalcy following such crises generally means exacerbation of these weaknesses that erode and threaten to fracture social, economic and political foundations. This paper documents social and economic policies across two financial crises, the Asian Financial Crisis and the Global Financial Crisis, for South Korea, the Philippines, and Indonesia, to reveal the problems from growth-centric recovery focus on economic fragilities, social cohesion, and political stability. Further, using evidence from the ground and survey data, we also show how recovery to a new normal with a reprioritization of social policies invigorates the social, political, and economic foundations. We round off the study with an examination of social policy changes under COVID-19 to assess how the efforts track against a recovery to business-as-usual economic normalcy or a new normal that reprioritizes social policies and the economy. The scope of change is high; as we show in the paper, it is also necessary.
\end{abstract}

Keywords COVID-19 · Crises · Business-as-usual · Economic recovery $\cdot$ New normal $\cdot$ Social policies

\section{Resumé}

Les crises et les bouleversements renvoient à des faiblesses sociales, économiques et politiques qui sont souvent évitées ou mises en sourdine afin de suivre les grands plans de croissance ou de développement. Le fait de se relever après une crise offre donc la possibilité de s'attaquer à ces problèmes sous-jacents qui ont précédé et, vraisemblablement, contribué aux crises ou aux bouleversements; en attendant, suite à de telles crises, un retour à la normalité d'avant signifie généralement une

O. Fiona Yap

fiona.yap@anu.edu.au

1 The Australian National University, Canberra, ACT 2601, Australia 
exacerbation de ces faiblesses qui érodent et menacent de fracturer les fondations sociales, économiques et politiques. Cet article documente les politiques sociales et économiques à travers deux crises financières, la crise financière asiatique et la crise financière mondiale, pour la Corée du Sud, les Philippines et l'Indonésie, afin de révéler les problèmes d'une reprise axée sur la croissance et de se concentrer sur les fragilités économiques, la cohésion sociale et la stabilité politique. De plus, en utilisant des preuves sur le terrain et des données d'enquête, nous montrons également comment la relance de l'économie sur la base d'une nouvelle norme, avec une redéfinition des priorités des politiques sociales, revigore les fondements sociaux, politiques et économiques. Nous terminons l'étude par un examen des changements de politique sociale dans le cadre de la COVID-19 pour évaluer de quelle façon les efforts s'opposent à une reprise du statu quo de la normalité économique ou à une nouvelle normalité qui redéfinit les priorités des politiques sociales et de l'économie. L'ampleur du changement est élevée; comme nous le montrons dans cet article, elle est également nécessaire.

\section{Introduction}

The catastrophic one-two punch from COVID-19 upended political, social, and economic life globally and left governments scrambling to respond on multiple fronts. As countries ease tentatively and uneasily to recover to life before the pandemic, a key question consistently raised is this: recovery to what? Should the outpouring of resources, efforts, funds, and time be aimed at a business-as-usual economic recovery? Or should they be targeted at recovery to a new normal beyond growth-centric revival? Winston Churchill's famous quip, "Never let a good crisis go to waste," is a reminder that crises and dislocations home in on social, economic, and political weaknesses all too often sidestepped or pushed to the backburner as a result of single-minded pursuits of master plans of growth or development. Recovery from crises to a new normal, then, typically means seizing the opportunity to reprioritize society, politics and the economy; for many countries, this entails expanding medium- and long-term social policies that address underlying social, political, or economic weaknesses that preceded and, likely, exacerbated the crises or dislocation. Meanwhile, a return to previous normalcy following such crises generally refers to a focus on growth-centric policies aimed primarily at an economic rebound. In practice, return to business-as-usual, then, fixates on economic normalcy; social policies, where adopted, are stop-gap measures that do not substantively address underlying shortcomings. Such a course leaves way for weaknesses to amplify and further corrode or even fracture their foundations. Despite the promises of a recovery to a new normal and the corresponding perils associated with business-as-usual economic normalcy, reprioritization with a new normal remains largely unrealized, even as a growing body of literature shows such a revamp improves economic fundamentals, political support and social relations for growth, particularly in the medium- and long-term (Stiglitz 2000; Bernanke 2009).

This paper joins this growing literature: it documents the economic, political, and social downsides of a business-as-usual growth-centric rebound and provides 
corresponding evidence that a new normal that incorporates medium- and long-term social policies_-such as environmental and social protection-promote political support and social cohesion for countries in East and Southeast Asia; further, we relate the findings to social policy changes under COVID-19 to assess how recovery efforts in the three countries track against the pursuit of growth-centric versus a new normal recovery. Specifically, we examine the experiences of three countries in East and Southeast Asia-South Korea, the Philippines, and Indonesia-across two financial crises, the Asian Financial Crisis (AFC), 1997-1998, and the subsequent Global Financial Crisis (GFC), 2007-2008, to show that the three countries primarily targeted recovery to economic normalcy following the AFC and the subsequent GFC, with social policies, where adopted, mostly temporary and ad hoc measures to facilitate economic recovery. These experiences largely mirror those of other countries in East and Southeast Asia. We provide qualitative evidence that show how the growth-centric recoveries increased economic vulnerabilities and social insecurity. Further, we provide quantitative evidence from systematic analyses of surveys to show the political and social benefits of medium- and long-term social policies. Specifically, we show respondents are impelled to protest to assert their preferences for social policies over economic performance; in addition, social trust is based on social policies rather than a growth-centric economic normalcy. And, we bring the discussion up-to-date by relating the relevance of the findings to social policy changes under COVID-19.

The East and Southeast Asia region is interesting for study: countries in the region are generally considered to be strong economic performers, so that the populace in East and Southeast Asian countries may be inclined to welcome a growthcentric, business-as-usual recovery, more so than peoples in other regions. In particular, these countries have earned accolades for their economic success, as the Asian tigers of South Korea, Taiwan, and Singapore, and the next Asian tigers of Indonesia, Thailand, Malaysia, and the Philippines. Indeed, a key pillar of the East Asian Development Model (EADM) - a growth model ascribed to countries in the region-is that economic achievements underpin citizens' acceptance of less-thandemocratic regime rules and processes to enable the government-led economic success in these countries, often pursued with the aid of illiberal rules, processes, or practices (Shrestha 2013; Cha and Yap 2020). Meanwhile, in stark contrast, social policies-such as social protection-are underdeveloped: social policies have historically been described as "productivism" or "developmentalism": i.e., they were left primarily to families and communities on the basis of mutual support while economic and industrial development objectives were prioritized by the state (Ratigan 2017). These depictions of East and Southeast Asia underline that citizens in the region may be inclined to embrace a return to business-as-usual economic normalcy. It stands to reason that if the examination reveals otherwise-that citizens in the region prefer and support a recovery to a new normal that incorporates medium- and long-term social policies - then the results are likely to be broadly generalizable.

To enhance generalizability, the three dissimilar countries of South Korea, Indonesia and the Philippines are chosen for examination from the population of East and Southeast Asian countries, i.e., we adopt the most different cases comparative method to augment external validity of the findings. Briefly, the most different cases 
or systems comparative method draws findings based on selection of cases from a defined population that vary across most of the relevant independent variables; as a result of such case selections, similar outcomes on the dependent may be mapped to the independent variables that are alike, i.e., they may be attributed to the remaining areas of similarities (Przeworski and Teune 1970; Collier 1993; Levy 2008; Mill 1875). ${ }^{1}$ By the most different cases comparative method, then, consistent outcomes across the cases undergird generalizability or external validity of the findings. And, to be sure, the three countries vary widely across culture, society, economic and political development. Thus, culturally and socially, the countries are diverse: South Korea is generally considered a Confucius society, the Philippines is primarily Spanish-Catholic, while Indonesia has the world's largest Muslim population, at $87 \%$ of the country's total population (Statistics Indonesia 2010). The countries also vary in terms of economic development: South Korea is a developed country that joined the ranks of the OECD in 2000 while Indonesia and the Philippines are generally characterized as emergent economies. Politically, the countries also differ: the Philippines was among the first non-democracies in East and Southeast Asia to democratize in 1986, followed closely by South Korea in 1987, while Indonesia's democratization occurred a decade later. Of the three, South Korea's political progress has been the steadiest, with Indonesia facing down an alleged coup in 2016 while the Philippines has witnessed attempted, plotted, and alleged coups in 1986, 1987, 1989, 1990 and, after a lull, in 2001, 2003, 2006, 2007 (Yap 2020).

What are similarities across the countries, then? Briefly, we show that the three countries pursued growth-centric return to economic normalcy that eroded economic fundamentals; we also draw on survey data for evidence that social policies and their prioritization enhance social cohesion and political stability to support a purposeful recovery to a new normal comprising expanded medium- and long-term social policies.

Thus, on the one hand, the almost single-minded focus on economic recoverywhere governments doubled down on efforts to strengthen economic growth captured nominally by Gross Domestic Production (GDP) and its variants-meant that most countries in the region appeared to withstand the crises well. As an indication, for the AFC, most countries in the region reported positive growths by 1999 , with South Korea, a country hard-hit during the crisis, leading the pack with doubledigit growth of $11.3 \%$ (World Bank Databank 2020); in contrast, Japan, a creditor during the AFC, reported negative growths in 1998 and 1999. As another indication, for the GFC, most countries in the region averted negative growths altogether; indeed, their recovery from the GFC well before counterparts in other regions led to renewed interest and enthusiasm in their economic success, yet again (Pempel 2015; Das 2012).

On the other hand, even as these economies returned to pre-crisis macro-level economic achievements, data from OECD, ILO, and the World Bank show large and widening gaps between the haves and have-nots, especially in the labour market.

\footnotetext{
1 We thank an anonymous reviewer for suggesting the need to flesh out the most different comparative case design.
} 
As a result, even as growths returned to normal for the East and Southeast Asian countries, they also experienced high incidence of low paid work and short average job tenure among the vulnerable population, including women, youths, the elderly, migrant workers, and those in the informal economy, i.e., the recovery to economic normalcy impaired core constituents of the labour market. Critically, studies note that such disparities and inequities undermine economic, political, and social foundations and leave countries susceptible to future shocks (OECD 2017; Stiglitz 2000; Basso et al. 2012; Birdsall 2011). Anecdotally, fissures are evident in the growing social divides and political discords in East and Southeast Asia, a region where the populace is traditionally seen as compliant and deferential. Witness, for instance, the Sunflower movement in Taiwan in 2014, the million-strong Candlelight protests in South Korea, 2016-2017, and the year-long protests in Hong Kong, 2019-2020. Meanwhile, the election of controversial and polarizing candidates-such as President Duterte in the Philippines, who campaigned on an anti-crime platform of shoot-to-kill, or Vice-President Ma'ruf Amin, the inactive chair of the Indonesian Ulema Council (MUI) and Rais Aam (supreme leader) of the Islamic mass organization Nahdlatul Ulama in Indonesia, whose orthodox views include advocacy of the criminalization of gay sex - threaten to permanently cleave politics and society (Yap 2019).

This paper makes three contributions: first, it reveals clear and growing economic vulnerabilities that follow growth-centric rebounds. In particular, we show increasing non-standard or high levels of informalization of employment in the three countries to corroborate the economic costs and resultant fragilities of growth-centric recovery on growth, particularly in the medium- and long-term. Second, it highlights how a new normal that incorporates medium- and long-term social policiessuch as environmental or social protection policies-invigorate social and political foundations; countries in the region, then, benefit from policies that go beyond growth-centric business-as-usual recovery. Thus, using survey data, we show popular support for social policies over economic growth, and respondents are motivated to protest for social policies; further, we show that respondents' social trust rests on social policies rather than economic growth. Medium- and long-term social policies, then, enhance political stability and social relations which undergird economic achievements in these countries; meanwhile, the temporary spikes in social policies that follow crisis do not bring the medium- and long-term policy benefits because the focus on getting back to business-as-usual means social policies adopted are not well formulated and often scuttled following the crises. Third, we examine social policies adopted under COVID-19 to assess the content of recovery for the three countries, given the clear lesson for COVID-19 recovery from this study: recovery needs to target a new normal that addresses social, political, or economic weakness through the expansion of medium- and long-term social policies. Our assessment reveals that, of the three countries in this study, only South Korea may be pursuing a reprioritization of society, politics, and the economy through social policies that are not just crisis-specific stop-gap measures. This highlights that most governments are pursuing growth-centric recovery, yet again, notwithstanding previous learning.

In the following, we give brief backgrounds to the country cases in this study before describing the crises and recoveries to show the growth-centric focus. We 
go on to provide evidence and systematic analyses of the problems of growth-centric economic recovery and the promises of a new normal that prioritizes mediumand long-term social policies. This is followed with a discussion of social policies adopted since COVID-19, and how they track against recovery to a new normal. We conclude with implications of the findings.

\section{Pre-Crisis Politics, Economies, and Social Policies}

This section provides brief backgrounds to politics, economy, and social policies in South Korea, Indonesia, and the Philippines prior to and following democratization. Using democratization as a demarcation follows theoretical and empirical findings that social policies expand post-democratization, i.e., democratization generally marks the turning point for expanding social policies (Yap 2006; Brown and Hunter 1999; Reich 1999). The three countries hew closely to this: social policies were significantly limited prior to democratization and expanded in the respective countries following democratization. Still, even with the expansions post-democratization, social policies remained limited and inadequate in the three countries. As an indication, social expenditure as a percent of GDP in 1995 was 3.1\% in South Korea, $0.7 \%$ in the Philippines, and $1.6 \%$ in Indonesia, respectively (ILO 2020a, b, c). In comparison, social spending for the OECD countries averaged $18 \%$ that year, while Turkey and Mexico-generally considered as about on par with the Philippines and Indonesia-spent $3.4 \%$ and $3.7 \%$ respectively (OECD 2020). Thus, even countries on the low end of social spending-such as Turkey and Mexico-significantly outspent their counterparts of Indonesia and the Philippines.

The limited offerings of social policies were particularly stark in light of the economic achievements of the countries. To be sure, even though much of focus on economic performance for countries in the region was during pre-democratization periods, the countries continued to achieve high economic growths post-democratization. This bears noting since it suggests the centrality of the economy and growth for governments in these countries.

Table 1 chronicles the social policies in South Korea, Indonesia and the Philippines against economic performance in pre- and post-democratization periods. It shows that social safety nets and social policies were largely limited to government employees and other sectors favoured by the governments in pre-democratization periods. Theory explains that governments in pre-democratized countries, such as authoritarian or military-backed governments, generally follow in the heels of military coups and stop-gap military governments and these latter lack broad-based support. To co-opt opposition, the pre-democratization governments may pursue a number of strategies, including: delivering policy performance, such as economic performance; holding popular, if limited, elections; or institutionalizing politics and society to co-opt opposition (Geddes et al 2014; Gandhi 2008). Unsurprisingly, the expense of expansive social policies meant they were limited in pre-democratization periods.

Column 4 in Table 1 shows an expansion of social policies in South Korea, Indonesia and the Philippines following democratization. This is consistent with 


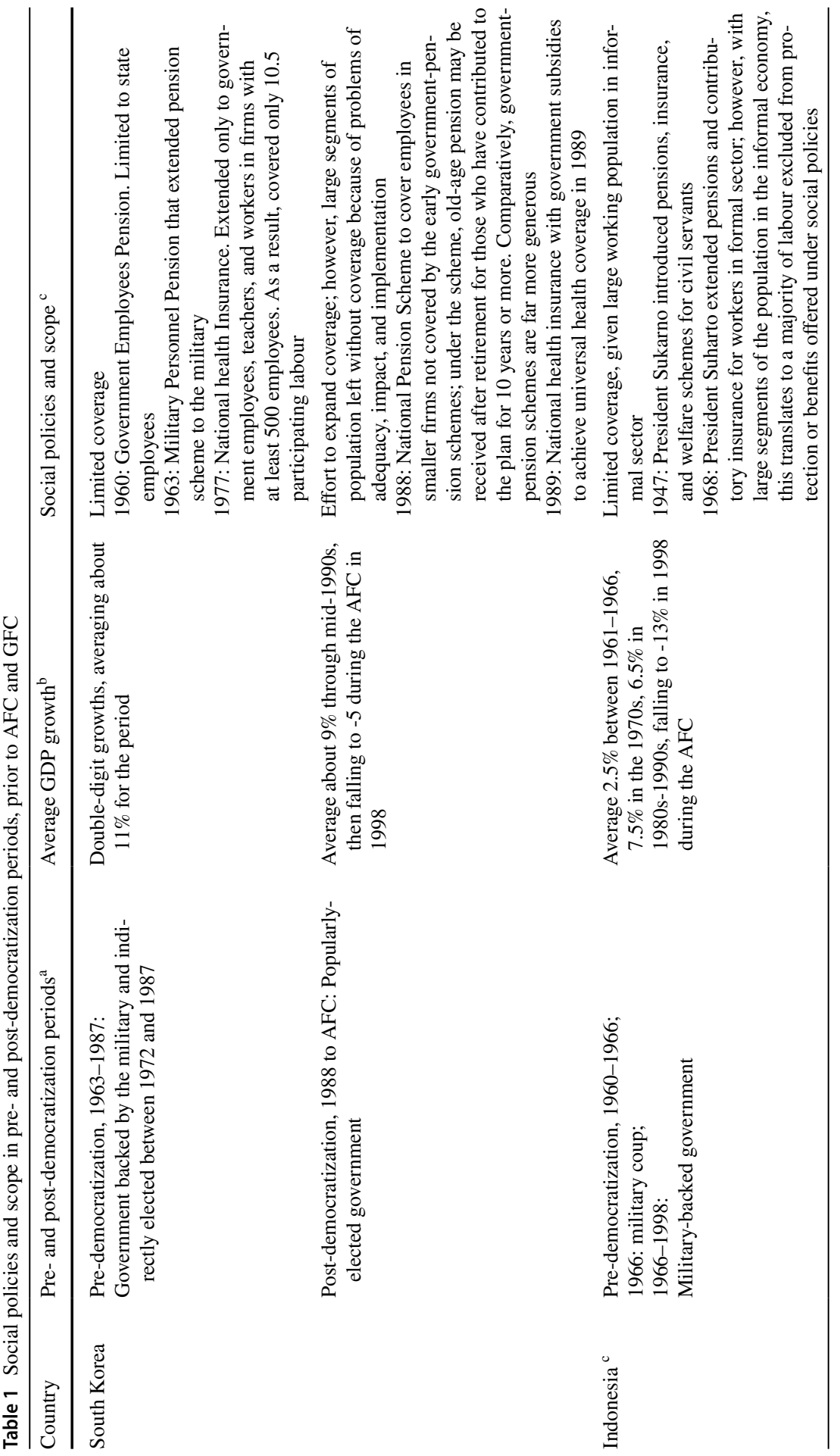

我 


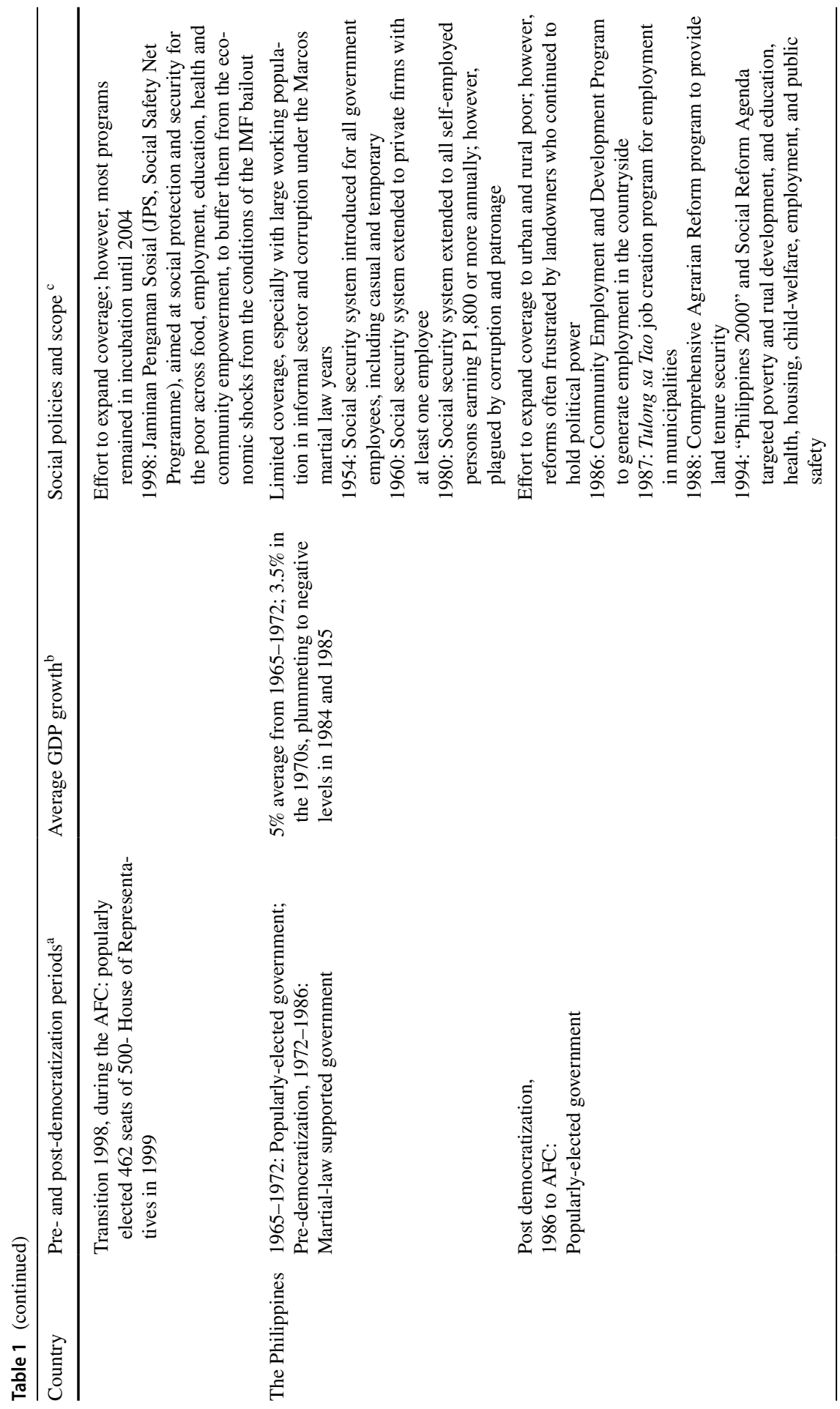




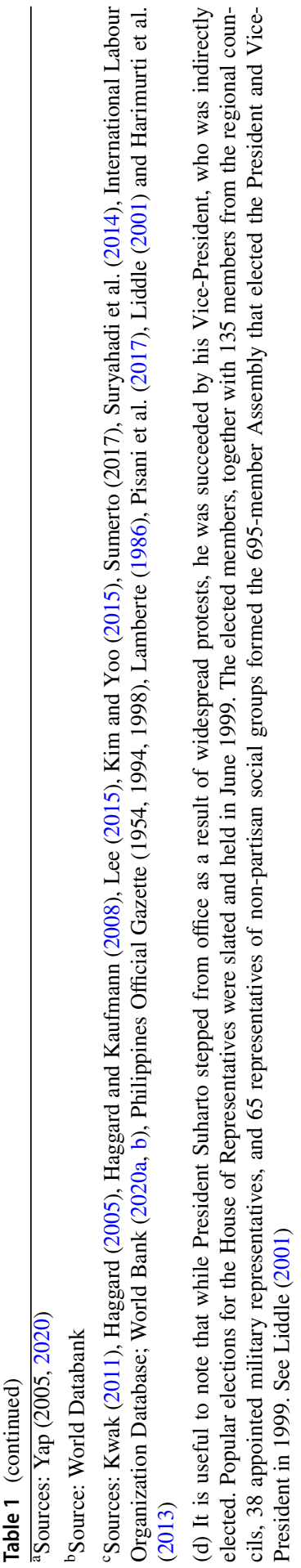

s 
theoretical studies that show democratization leads to increased spending as governments use social spending to build and broaden electoral support (Yap 2006; Brown and Hunter 1999; Reich 1999). In particular, governments in new democracies are incentivized to increase expenditures, particularly since the emerging institutions and rules may foster immediate accommodations to constituencies and discourage long-term planning. Still, notwithstanding the increases in social policies, they remained considerably less extensive and generous in East and Southeast Asia than western welfare regimes (Ratigan 2017).

Not surprisingly, crises such as economic or financial crashes provide shocks that bring to light inadequacies in social policy coverage in countries. Problematically, as will be made clear in the next section, growth-centric recovery from such crises generally papers over gaps in social policies; this compromises growth in the medium- and long-term because of added economic vulnerabilities, and also undermines political stability and social relations. We turn next to the AFC and GFC and the growth-centric recoveries in South Korea, the Philippines, and Indonesia.

\section{Crises, Growth-Centric Recoveries, and Social Policies}

Economic achievements across decades in East and Southeast Asia in general, and the three countries in this study in particular, likely dulled critical assessments of the economies or the inadequacies of social safety nets in the countries. It is fair to say that the AFC blindsided the international community; notwithstanding, analysts made up for lost time and the misstep with unremitting analyses of how governments in the region, who could do no wrong before the crisis, were unable to get anything right since (Cha and Yap 2019). Generally, these advocated for free market reforms to further open the economies.

In this section, we show that free market reforms in the context of the growthcentric recovery strategy in the region accelerated the casualization of the labour market to the detriment of economic fundamentals (Bernanke 2009; Stiglitz 2000; Reinhart and Rogoff 2004). At the same time, the AFC and subsequent GFC illuminated the extent to which social policies were underdeveloped: large segments of the populations in the respective countries remain without benefits or protection, despite the social policies in place.

In brief, in the face of the pressing demands of economic recovery and social policymaking, governments in the three countries stuck with the modus operandi of prioritizing the economy rather than reprioritizing social policies with economic recovery. The growth-centric focus on recovery to economic normalcy in these countries means that social policies adopted under crises were piecemeal responses aimed at averting further immediate fallout from the crises and, thus, mostly weak, inadequate, ineffective, and, easily scuttled following the crises. These become apparent with the subsequent crises: thus, the AFC shed light on the inadequacies of social policymaking, the GFC illuminated ongoing ineffectual social policy responses, and Covid19 revealed the perilous conditions that remains across countries for vulnerable labour and the poor, particularly women, youths, the elderly, migrant workers, and those in the informal economy. These persistent social, political, and economic 
weaknesses have contributed to the deterioration of social relations and political stability across the three countries.

\section{Economic Policies and Consequences}

Table 2 summarizes the AFC and GFC policies adopted and the economic consequences from the policies. It is useful to point out that the growth-centric economic recovery for the AFC was due in no small part to the demands associated with the IMF bailout of countries from the AFC: in particular, stringent conditions of the IMF bailout pegged funding to the recipient country's economic performance. Under these circumstances, the governments in the three crises-countries, all of which received IMF bailouts, may have little choice but to double-down on economic revival.

Thus, among the remedies adopted to deal with the crisis was the establishment of the International Monetary Fund (IMF) as a lender of last resort for the crisiscountries. This turned out to be a double-edged sword. Specifically, the IMF financial rescue package tied aid to the countries' commitments to high interest rates, severe cuts in government spending, accumulating foreign exchange reserves, and also non-financial structural changes such as market reforms and labour market deregulation for the domestic economy, among other conditions; further, continuation of aid from the bailout was pegged to recoveries in the countries as measured by economic output, debt repayment and budget surplus (Radelet and Sachs 1998; Stiglitz 2000; Cooke and Jiang 2017).

In the years since the AFC, there is also increasing agreement, including from the $\mathrm{IMF}$, that a number of the IMF measures which focused on growth-rebound deepened the crisis: for instance, the high interest rates and constricted domestic spending are widely considered to have worsened conditions. And, the IMF's stipulation of the quick shut-down of unviable financial institutions contributed to panic runs on the bank, to which foreign lenders responded by rejecting further discounts of loans, which squeezed the capital market even tighter (Radelet and Sachs 1998; Stiglitz 2000; Fischer 2000).

It is no small irony that the uncompromising conditions of the IMF bailout of countries during the AFC led to the under-development of the financial markets in the region that effectively isolated countries in East and Southeast Asia from the machinations that preceded the GFC (James et al 2008; Bernanke 2009). Largely following from the IMF conditions, then, the Asian economies missed out on the risky subprime and derivatives market that underpinned the GFC, due in part to stricter policies and the constricted foreign lending as a result of the AFC and in part to the underdevelopment of financial markets in Asia as a result of the uncompromising bailout (Pempel 2015; James et al 2008; Bernanke 2009). Table 2 lists some of the economic reverberations: thus, for instance, while growth figures may suggest that the countries recovered from the AFC, deeper examination of non-performing loans or unemployment rates shows the economies struggled longer and harder to stay afloat as a result of the growth-centric focus (Stiglitz 2000; Haggard 2005; Radelet and Sachs 1998). 


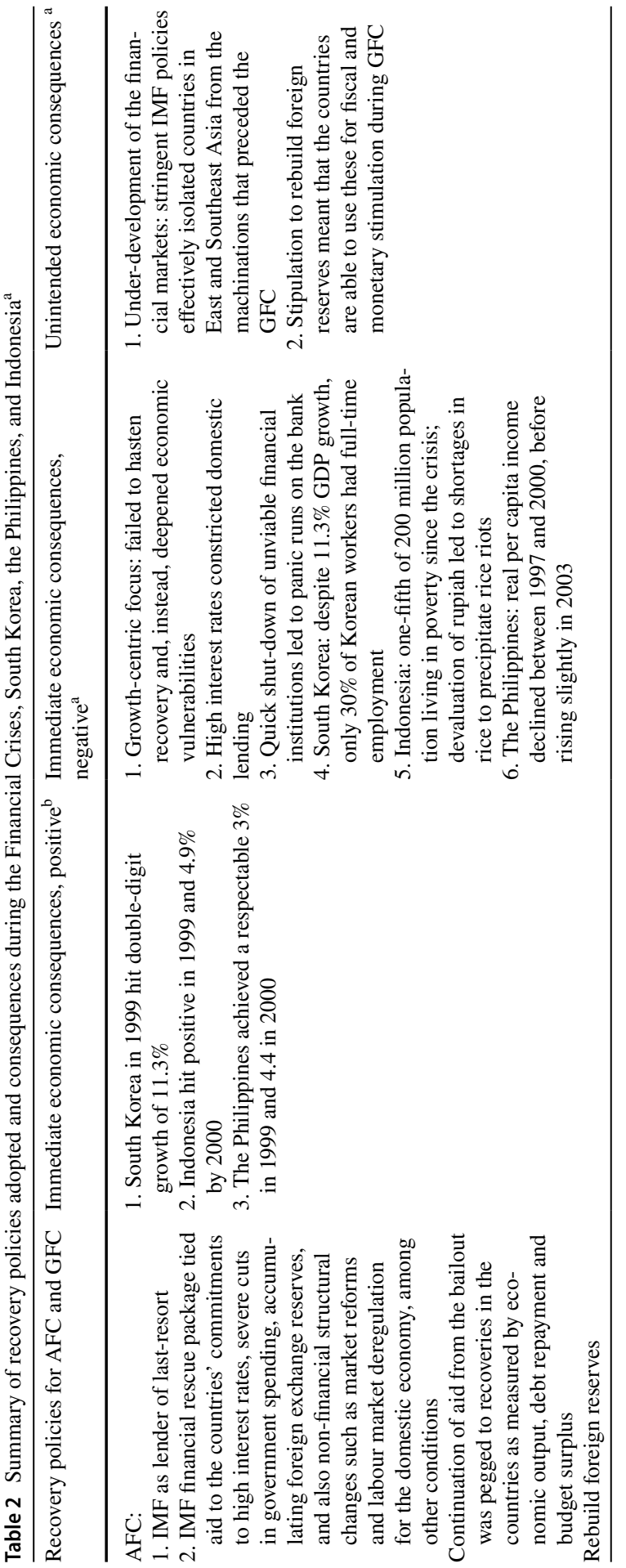




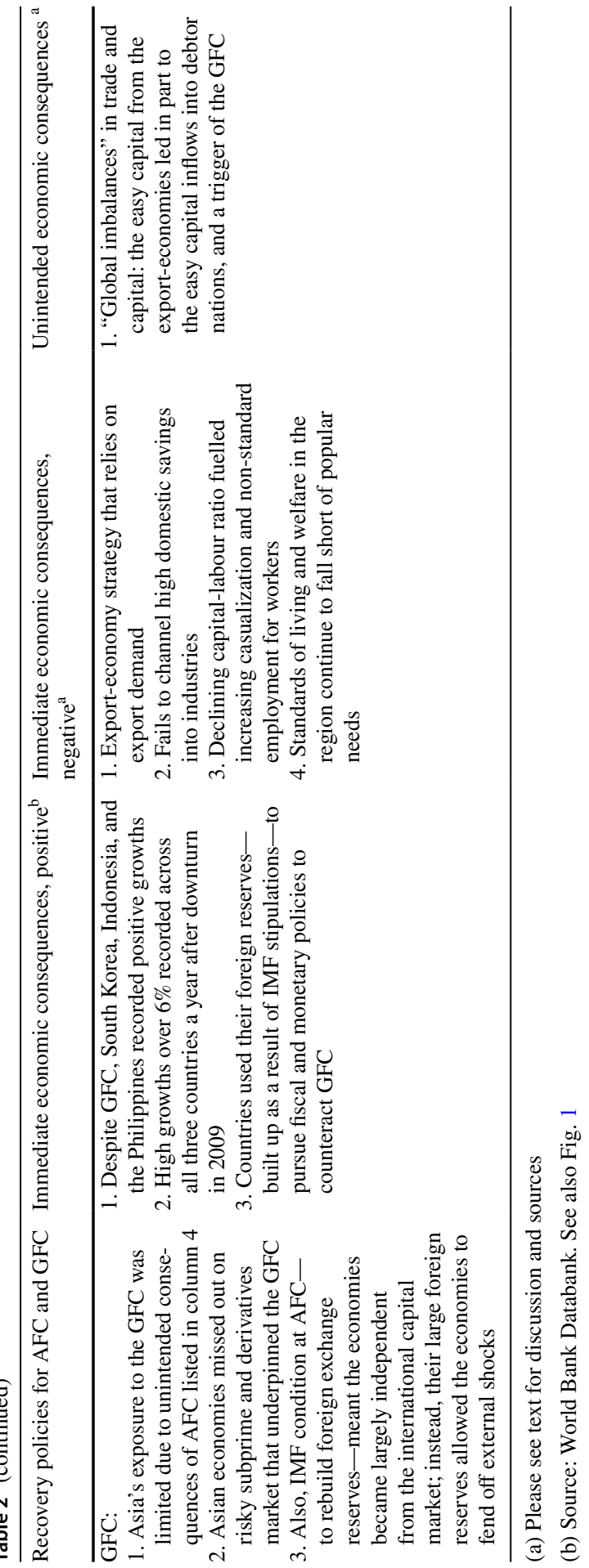

选稀 


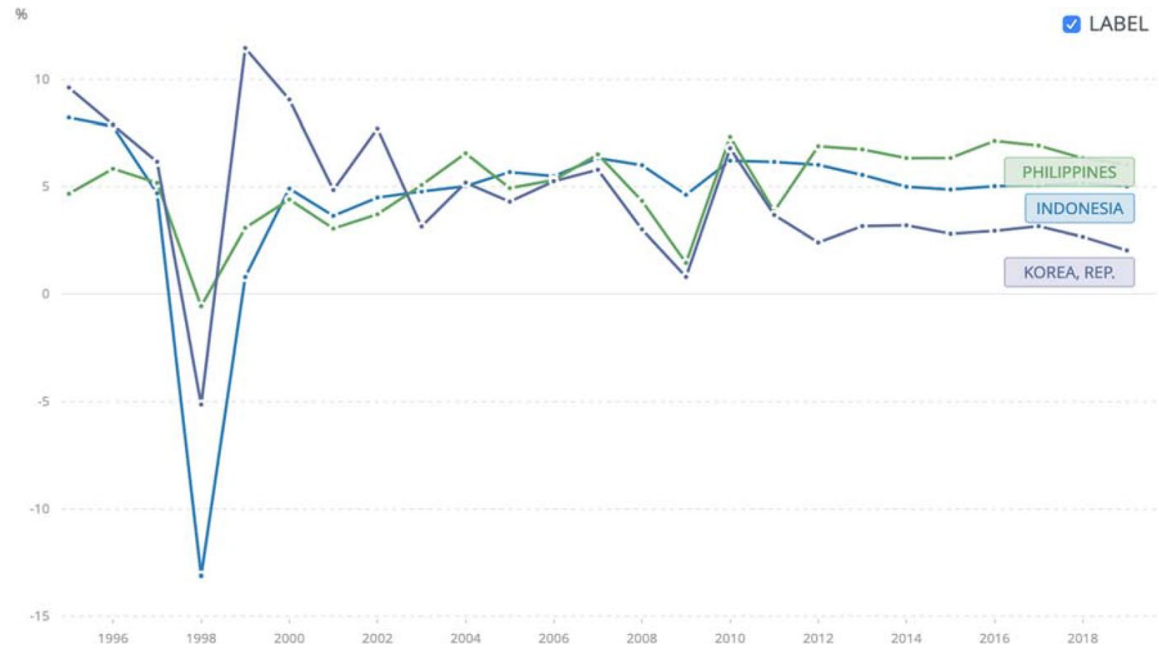

Fig. 1 GDP Growth (constant) in South Korea, Indonesia and the Philippines, 1996-2000. Source: World Bank Databank (2020)

In consequence, Asia's exposure to the GFC was limited: the subprime loss in Asia excluding Japan was US\$10.8 billion-Japan itself, which was not subject to the conditions of the IMF's bailout, carried US \$ 8.7 billion-while the total "reported write-down and credit losses of the world's 100 biggest banks and securities amounted to US \$ 379 billion" (James et al 2008, p. 25). In relative terms, Asia’s exposure excluding Japan was "less than $3 \%$ of the global losses"; including Japan, it constituted only $5 \%$ of global losses (James et al 2008, p. 25). The limited exposure of East and Southeast Asia to the financial GFC meant that economic downturn for countries in the region followed from the global trade slowdown rather than the financial crisis itself. Figure 1 depicts GDP growth in South Korea, Indonesia and the Philippines from 2000 to 2019; it shows that the economies largely averted negative growths and, further, growths in the high single digits were recorded across the countries a year after the downturn in 2009.

The economic travails from the growth-centric recovery for the AFC, then, left countries in East and Southeast Asia, including South Korea, the Philippines, and Indonesia, relatively unscathed by the GFC (Bernanke 2009; Dutt 2013). And, the IMF condition - to rebuild foreign exchange reserves-also meant the economies became largely independent from the international capital market; instead, their large foreign reserves allowed the economies to fend off external shocks (Bernanke 2009; Dutt 2013).

However, it also clear that the course of recoveries for East and Southeast Asian economies rested on an export-economy focus. While that provided current account surplus to the surmount the GFC hump, it also undermined their respective domestic economies. Specifically, the growth strategy in post-AFC and -GFC East and Southeast Asia is one that relies on external demand through the export-economic focus that built large foreign reserves but also contributed to the "global imbalances" in 
trade and capital, with the easy capital inflows into debtor nations pinpointed as a precipitant of the GFC (James et al 2008; Bernanke 2009). Domestically, this growth strategy failed to channel the high domestic savings into domestic industries; instead, with capital-labour ratio declining, it fuelled a "race-to-the-bottom" wages with increasing casualization and non-standard employment for workers (Cooke and Jiang 2017; ADB 2005). Consequently, standards of living and welfare in the region continue to fall short of popular needs (Bernanke 2009; James et al 2008). We turn next to social policies and their development under the crises.

\section{Social Policies Under Growth-Centric Recoveries}

The growth-centric economic rebounds from the AFC and the GFC, rather than a new normal that reprioritizes medium- and long-term social policies, means that social policies fell easily to the wayside (Bernanke 2009; de Haan 2014). To be clear, social policies were adopted during the crises; nonetheless, their scope fell short of needs and the schemes suffered from coverage, adequacy, impact, and implementation problems.

Thus, social policies adopted under growth-centric recoveries in South Korea suffer from the general problems of coverage, adequacy, impact, and implementation, so that even as policies expanded, they failed to provide needed social support to large segments of the population. For example, unemployment insurance in South Korea supplemented labour flexibility and international ownership that led to high informal unemployment; further Kwon and Holliday (2006) point out that part-time and temporary workers were excluded so that, as a result, in practice, only $52 \%$ of salaried workers were covered (246). As another example, the National Basic Livelihood Security was implemented in 2000 as a public aid program to maintain basic living standards following the AFC; however, eligibility was strict, which severely limited coverage (Lee 2015). This became apparent with the GFC: while the scheme extended benefits to $3 \%$ of the total population, or 1.5 million, studies estimated in 2013 that an additional 1.2 million who should receive benefits were deemed ineligible (Lee 2015; Kwon and Holliday 2006). In 2015-eight years following the GFC - the program was overhauled to improve coverage and benefits.

Similarly, in Indonesia, social policies such as the JPS that were enacted in the heels democratization and the AFC was found lacking across coverage, adequacy, impact, and implementation: for instance, separate assessments by the Asian Development Bank (ADB) and the Overseas Development Institute (ODI) found a large number remained outside of the JPS scheme, with many of the eligible poor not receiving benefits even as many non-poor collected them (Sumarto 2006; ADB 2012; Suryahadi et al. 2015). As a result, and with the onset of the GFC, a community health insurance initiative, Jamkesmas, fully subsidized by the government that allowed local governments to design programs for their locality had to be adopted. In addition, political will behind the social policies was weak: thus, the JPS, adopted in 1998, remained in incubation until 2004; meanwhile, a consolidated National Social Security system, debated since 2004, was finally enacted only in November 
2011, following the Law on Health Social Security Providers (No. 24/2011) which created the Badan Penyelenggara Jaminan Sosial-Kesehatan (BJPS, the Social Security Administration), with targets for universal health insurance coverage and work injury, old age and death insurance (Harimurti et al 2013; Pisani et al 2017).

In the Philippines, successive presidents since democratization have adopted pro-poor platforms in election campaigns but few successfully translated these into practice. Consider President Estrada, elected on a populist platform in the heels of the AFC: he spectacularly failed to deliver on his program of subsidised health care for the poor (Lingap Para sa Mahihirap, or Looking after the Poor), due mostly to corruption (Kim and Yoo 2015); in 2001, the President was ousted from office for corruption by the People Power 2 protests. President Arroyo, who stepped into the office following Estrada between 2002 and 2010, did not fare better for much her tenure, even as the country held to a strong $6 \%$ average economic growth prior to the GFC and despite her poverty reduction programs. Instead, the growth failed to translate into significant job-creation: indeed, Coronel (2007) cites an ADB 2006 report that found the country's performance on malnutrition, education access, and water availability on par with the poorest countries in the world, including Myanmar and Papua New Guinea (182).

Importantly, there were also high notes for social policies during these recoveries that give reason for optimism regarding the former's effects. Thus, in Indonesia, local autonomy Laws No. 22 and 25 in 1999 which devolved administration of government sectors excepting security and defense, foreign policy, monetary and fiscal matters, justice, and religious affair, to district and municipal governments effective 2001, and the institutionalized elections for local executives, saw local governments step up to develop popular social policies, particularly health coverage, in order to win local support for office (Choi 2005; Nasution 2016). One such standout was Gede Winasa in the Balinese district of Jembrana, which, importantly, is one of the poorest areas in the country. Winasa initiated a health program for outpatient services for all residents, and hospitalization for the poor, and the significant improvement in health services and mortality rates led to Winasa's election as district head with $90 \%$ of the votes (Pisani et al. 20,187). It also drew widespread attention to health schemes, and motivated the nationally-run Askesin health scheme in 2005, which in turn became Jamkesmas in 2008 (Pisani et al 2017).

Likewise, in the Philippines, with the GFC and further motivated to build constituency base to offset the attempted impeachments in 2005, 2006, 2007, and 2008, President Arroyo got behind the 4Ps (Patawid Pamilyang Pilipino Program), a conditional cash transfer (CCT) program piloted in 2007 and formally implemented in 2008 (Coronel 2007; Kim and Yoo 2015). President Aquino III, 2010-2016, significantly expanded the program, and took the original 320,000 households or 1.2 million in population terms, to the 4.4 million households in 2015 or approximately 18 million in population of 103 million total population (Acosta and Velarde 2015). It has become the most successful social safety net in the country and touted by the World Bank as "one of the most comprehensive poverty targeting programs" in the world, targeting education and health through grants provided in exchange for keeping children in schools, maintaining basic healthcare for children as well as expectant mothers (World Bank 2020a, b; Acosta and Velarde 2015). With an estimated 
5.2 million households at poverty level, or about $21.6 \%$ of the population, the program covered most of its target in 2015 (Orbeta and Paqueo 2016).

In sum, the secondary standing of social policies under growth-centric recoveries largely saw problems of coverage, adequacy, impact, and implementation. Nevertheless, high notes during these recoveries gave reason for optimism. Next, we discuss the effects of growth-centric recoveries on the economy, politics, and society in subsequent decades.

\section{Growth-Centric Recoveries on Economy, 10 Years on}

Governments that prioritize the economy often characterize such efforts as beneficial to all: growth trickles or filters down across all sectors, and does so more efficiently than deliberate state intervention (Headey et al 2000; Stiglitz 2016). However, studies show otherwise. For instance, Headey et al (2000)'s study of the US, Netherlands, and Germany between 1984 and 1999 show that growth did not trickle down better or more efficiently in the US than either Netherlands and Germany; in fact the US did worse than either country in improving living standards across the population. Further, economic growth in the US did no better than either other country, to reveal no upsides to chasing economic growth over welfare goals. Recent studies across developed and emergent economies continue to corroborate the absence of efficient trickle-down growths (Stiglitz 2016). And, the Human Development Report (1999) points out that "real wages take an average of three years to pick up again, and that employment growth does not regain pre-crisis levels for several years after that" (4). In this section, we provide evidence that growth-centric recoveries negatively impacts the East and Southeast Asian economies in at least three ways: increased dualization of the labour markets that does not improve with growth levels; poor earning quality; and vulnerable groups including women, youths, elderly, and the disadvantaged disproportionately and heavily comprising casualized and temporary labour.

Specifically, extant studies show that financial crises contribute to the further dualization of labour markets (Reinhart and Rogoff 2004; Eichhorst et al. 2017; Steindel 2009; Basso et al. 2011). Thus, even as financial crises lead to large redundancies across sectors, recovery is generally uneven across market sectors as well as socio-economic groups. Instead, policies targeted at hastening recovery broadly are often less effective at redressing conditions for targeted groups: women, youths, the elderly, and the disadvantaged are particularly vulnerable. Disparities in the labour market, then, widen; this increases duality in the labour market, which continued economic growth is unlikely improve.

Evidence from the three economies corroborates this. Thus, the countries in this study saw recovery success at the macro-economic level: for instance, Korea's per capita income stands at US\$31,380 in 2018, compared against the OECD memberaverage of US $\$ 40,427$. However, alongside these positive numbers are dismal ones: as an example, South Korea's earnings quality, measured in constant prices with purchasing price parity (PPP) was US\$10.39 for the most recent data available in 2014 (OECD Stat 2020). This fell in the lower half among OECD members, and 
was higher than Greece, which reported US $\$ 9.70$ but less that Slovenia, which was US\$14.49 (OECD Stat 2020). Likewise, per capita GDP in 2018 for Indonesia and the Philippines at US $\$ 3,893$ and US $\$ 3,103$ respectively, which represented their best performance to that date, and placed both countries above the performance of lower middle-income countries (US \$2217); however, measured in constant prices with PPP, both countries fell below the performance of lower-middle income countries (World Bank Databank 2020).

Further examples of economic vulnerabilities is seen in the increased dualization of the labour market in South Korea following the consecutive financial crises. In 1998, average tenure for jobs was 6.1 years in the country; this fell to 5.9 years in 2016, with $30.9 \%$ in employment for less than 1 year. In contrast, the OECD average was 9.3 years in 2016, which increased from 9.0 in 2005, while $17.6 \%$ of jobs across the OECD were for less than 1 year (OECD 2018a). Tellingly, job tenure in South Korea remains the lowest across OECD members.

Another area of grave concern for South Korea is youth employment, i.e., the 15-24 youth group, given findings of unemployment and underemployment scarring that affects long-term production and the country's aging population (Arulampalam et al 2001; Brandt and Hank 2014; Mavromaras et al 2015). Unemployment and underemployment scarring refers to the loss in human capital through work experience and general skills as a result of unemployment spells that affect future earnings, so that future earnings would be lower than if such unemployment or underemployment had not occurred (Arulampalam et al 2001, p. F577). In South Korea, unemployment rate for the 15-24 age group was 3.85, 7.3\% and $15.5 \%$ in 1996, 1997 and 1999 respectively; in 2019, it was 11\% (Global Economy 2020). Employment for that age cohort, then, never recovered to pre-crisis levels. Meanwhile, the employment to population ratio of the 15-24 age group is $27 \%$ in 2019; the same ratio is $41.3 \%$ among OECD-members (World Bank Databank 2020). These indicators point to poor long-run economic outlook for the country.

For emerging economies such as Indonesia and the Philippines, the size of the informal economy, particularly employment in the informal economy, represents a significant economic vulnerability for medium- and long-term growth, to the extent that the International Labour Office (ILO) has adopted the formalization of the informal labour market as a key development goal for the 2030 agenda (OECD 2018a, b; ILO 2020a, b, c). The informal labour market is characterized by job insecurity, with lower wages, rights, benefits, working conditions, training, and protection than the formal labour market (Cooke and Jiang 2017; OECD 2018a, b). In Indonesia, 76.5\% of the workers were employed in the informal market in 2018 (World Bank Databank 2020). As reported by the OECD for 2016, this Indonesia's informal employment rate is the second highest compared to its peers of nine countries in Latin America and Africa; further, the number of youths (15-24 years) and elderly (over 55 years) in informal employment exceed even this high rate (World Bank Databank 2020). Similarly, in the Philippines, the last survey completed in 2008 with UN funding pegged $70 \%$ of the workers in the informal market; more recent Labor Force Surveys by the Philippines Statistics Authority (PSA) estimates informal workers as comprising $62.8 \%$ of the workforce, which is not far off the estimates of $70 \%$ by the ILO (Bersales and Ilarina 2018). 
To summarize, evidence from South Korea, the Philippines, and Indonesia show that economic fragilities persist even as the countries may have achieved economic normalcy in terms of growth. Next, we show the effects of growth-centric focus on society and politics.

\section{Quantitative Evidence: Growth, Society and Politics}

Economic vulnerabilities are not the only consequence of the growth-centric recoveries; in this section, we systematically analyse surveys to show that political and social instability increases with a focus on economic normalcy. Specifically, we examine protest activities and social trust to consider the extent to which the increased social and political instability may reflect changes in popular demand for social policies over economic performance.

Our focus on protest takes into account the rise in protests globally, particularly following the severe economic dislocation of the GFC. Further, and notably, protests have packed a punch in the countries in this study, toppling one regime and one government in the Philippines, and one regime each in South Korea and Indonesia. Protests refer to unconventional participation outside of institutionalized processes to influence political or policy outcomes. Previous work on protest activities have focused on how the economic performance-whether personal finance or the national economy-may motivate individuals to protest. However, recent studies show that preferences that lead to protest activities may not be about the economy per se but, rather, over redistributive policies, social programs or against austerity measures that dilute social- or public-goods. At a minimum, then, severe economic crisis may call attention to the lack of social benefits or their vulnerability to reduction with government efforts to redress economic dislocation (Justino and Martorano, 2019; Beissinger and Sasse 2013).

Meanwhile, our consideration of social trust is driven by in part by Putnam's (1993) work on social capital that spurred studies on social trust and its effects. Specifically, social capital-comprising social or generalized trust, social norms, and associational activities - is seen to facilitate social connections and coordination, and promote social cohesion (Putnam 1993; Cook 2005). Social trust generally captures trust in others to be upstanding in a social exchange. Studies on social trust show that at the individual level, social trust leads to more socially active, positive, and tolerant participants; at the social level, social trust engenders stronger support for democratic institutions and stronger social solidarity with "people who are different from ourselves" (Rothstein and Uslaner 2005, p. 45). Social trust, then, is a win-win proposition that enriches individuals and the society that they comprise.

To make the quantitative assessment, we use survey responses over time to study the individual's preference for economic programs over social policies on their willingness to protest; we also evaluate whether economic growth builds social trust. We rely on the World Values Survey (WVS) for the survey data: WVS has been documenting public opinion since 1981, and is currently conducting the seventh wave of surveys across the globe (World Values Survey 2020). 
The expansiveness of the WVS over time means that data are available for beforeand after-crises analyses.

We adopt variables based on their relevance as depicted in the literature and also their availability across countries and time for the three countries in this study. In particular, we examine the effects of four independent variables of interest-government responsibility for providing for everyone; environmental protection versus economic growth; economic growth as primary aim of the country, and satisfaction with household finance-on two dependent variables-social trust and protest participation-controlling for demographics and other relevant controls. Briefly, the first three the independent variables capture popular preferences for social versus economic priorities; the fourth-satisfaction with household finance-represents subjective, egotropic pocketbook interests, which may indicate the effects of economic vulnerabilities on social trust and protest activity. Descriptive statistics for the variables used are tabled in Appendix 1.

The effects of these independent variables are evaluated against two dependent variables: social trust, and protests. Social trust is generally captured in surveys as trust in others to be upstanding in a social exchange; it is reflected in the WVS through responses to the question, "Most people can be trusted," measured on a 2-point scale $(1=$ yes; $2=$ cannot be too careful). Protests are documented in the WVS by a 2 -point $(1=$ yes; $2=$ no $)$ question on political action: have you attended peaceful demonstrations? Both variables are recoded on a $0-1$ scale and inverted from the original for analyses and ease of interpretation.

Control variables include the standard demographic controls of education, age, and gender (Yap 2019; Gomez and Wilson 2006). Other control variables include interest in politics and institutional confidence. Interest in politics captures in part respondent's facility to follow politics and developments in the country, while institutional confidence-captured with two variables, confidence in the government, and confidence in parliament-takes into account satisfaction with government performance, measured on a 4-point scale, ranging from none at all to a great deal.

What do we expect to find? If economic growth promotes social trust and political stability, then some of the variables capturing economic prioritization, including economic growth as top priority or prioritization of economy over environment will be statistically significant and positive. However, if social policies are important, then some of the variables capturing social needs will be statistically significant; these include other priorities over the economy, prioritization of environment over economy, government responsibility, and household finance. We note here that responses to the question on environmental protection fall across three possibilities of prioritization of economy or the environment; given the structure of the question, the categorical responses to the question are recoded into three dichotomous variables, with prioritization of the environment over the economy as one of the dichotomies, pursuing economic growth as a priority as another, and neither environment or economy overriding as a third dichotomy.

Table 3 reports the results of the pooled logit analyses of protests and social trust for the three countries. Columns 1 and 2 report the results for protests for pre- and post-crises periods respectively, and columns 3 and 4 report the results for social trust for pre- and post-crises surveys, respectively. In general, the results support the 


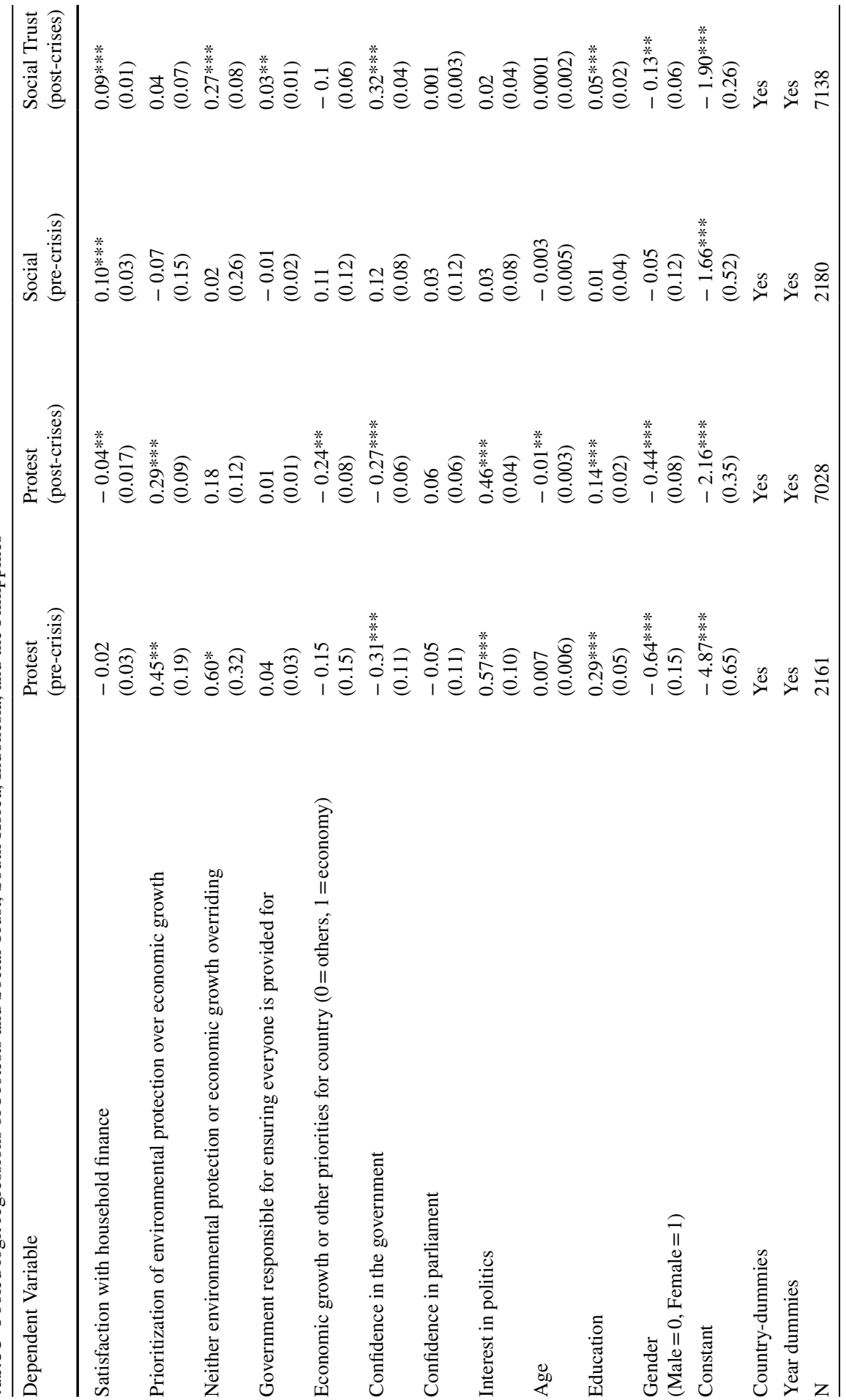
站。 


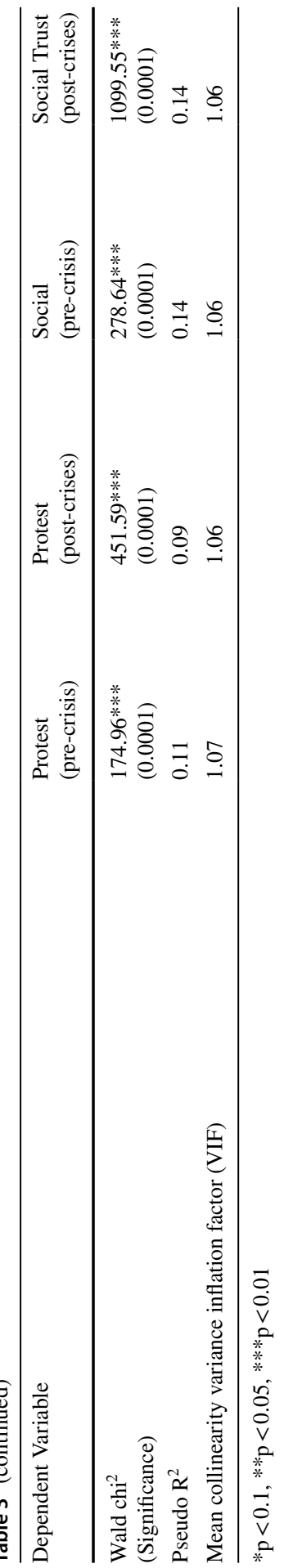


ascendance of social policies over economic growth to explain protests and social trust, i.e., responses report the importance of social policies in motivating protest mobilization and social cohesion. Also noteworthy are the statistical significance of the control variables, such as gender, education, confidence in the government and interest in politics: the significant variables are consistent with the literature and in the direction expected. Together with the explanatory value of the models as reported by the Wald-chi statistic and the low collinearity variance inflation factor, they lend confidence of the robustness of the model and generalizability of the results.

Thus, columns 1 and 2 show that those who value environmental protection over growth is statistically significant in pre- and post-crises periods for explaining protest, while those who consider neither environmental growth nor growth to be overriding is also significant in pre-crisis periods. Importantly, satisfaction with household finance and economic growth as a priority are statistically significant and negative for protest participation. Put another way, those dissatisfied with household finance are more likely to protest; in the post-crisis situation of economic vulnerabilities, this variable highlights problems that may ensue from economic normalcy recoveries that fail to address social, political, and economic weaknesses. Likewise, those who consider other priorities, rather than economic growth, as important for the country are more likely to protest. Protestors, then, are not driven by the prioritization of economic growth; it follows that prioritization of growth does not enhance political stability.

For social trust, the results for pre-crisis period shows only one of the variables of interest is statistically important in explaining social trust: satisfaction with household finance is statistically significant; that changed following crises and the results report that additional variables of interest to be significant in explaining social trust and in the direction expected. In particular, government responsibility for providing is statistically significant and in the direction expected; also, the variable measuring neither environmental protection nor growth as overriding is statistically significant and positive. In conjunction, the post-crises results suggest reprioritization of society, economy, and politics to be important for social trust.

In sum, evidence from the ground as well as systematic analyses reveal the consequences of social and political instability from a recovery to economic-normalcy where social policies play secondary roles. In particular, evidence from the ground show the failure to reprioritize society, economy, and politics have led to fractures in the form of widening cleavages in politics and society that have also contributed to protests and demonstrations, and fuelled regime changes or government turnover. Systematic analyses of survey data corroborate these conclusions: they show that economic growth fails to promote social trust or political support. Instead, results show that, post-crises, social trust and protests are explained by pocketbook finance concerns as well as broad social policy issues over economic growth. The clear lesson based on the experiences of AFC and GFC recovery for the three East and Southeast Asian countries in this study is this: a new normal that reprioritizes social building, economic growth, and politics with social policies. 


\section{Social Policies Under COVID-19}

In general, governments have responded to COVID-19 with a slew of social policies for their respective countries, and the ones for the countries in this study are not different. However, as we have shown in the foregoing, what critically matters is not whether social policies are adopted, but whether the social policies constitute a reprioritization to new normal, or if the social policies are secondary to a growthcentric economic normalcy recovery. How well do the social policies that have been adopted with COVID-19 track against recovery to a new normal?

Gentilini, Almenfi and Orton's The Global Review of Social Protection Responses to COVID-19 site contains a "living-paper" updated to track social policies, specifically social protection policies, adopted across countries since the pandemic hit in early $2020 .^{2}$ Social protection generally comprises social assistance, social insurance, and labor market regulations (Hickey et al. 2018; Handayani 2016). The authors show that South Korea, the Philippines, and Indonesia to be among the first documented to battle the economic and social dislocation from the pandemic (March 27, 2020).

Thus, the Philippines implemented five new cash programs alongside its 4Ps scheme specifically as COVID-19 response, to low-income families, those in the informal sector, and the country's most vulnerable for two months. Other measures include P1.2 billion has been set aside to cover unemployment benefits for a projected 30,000 to 60,000 workers expected to be laid off due to the economic dislocation (Gentilini et al. March 27, June 12, 2020).

Indonesia also adopted a cash transfer program for low-income households, for a period of three months starting in April; in addition, extra funding for a national food subsidy program was adopted to expand subsidies and coverage to nine months. Utility and mortgage waivers have been adopted, and US\$200 million set aside to finance health insurance for 30 million workers in the informal labour market (Gentilini et al. March 27, June 12, 2020).

Of the three countries, South Korea may be the most comprehensive, offering programs across social assistance, social insurance, and labour market support. These include childcare program to support homecare in low-income families as children shifted out of daycare, cash transfers for unemployed in low-income households; job seekers' cash transfer allowance of up to three months for low-income households and a 3-month wage subsidy for employers to retain employees (Gentilini et al. March 27, June 12, 2020).

How well do these policies track against a recovery to a new normal? In general, the social policies are targeted at COVID-19 relief; this is particularly true in the case of cash transfers, which are generally one-off or temporary. Further, while the crop of COVID-19 policies adopted in the three countries are extensive and cover large segments of the poor and the vulnerable, including women, old, youths, migrant workers and the homeless, over a longer period than previous policies, the

\footnotetext{
${ }^{2}$ We thank Keetie Roelen for suggesting the resources on the site, https://www.ugogentilini.net/
} 
expansiveness likely speaks more to the extent of the dislocation from the pandemic than to a reprioritization of society, politics, and economy.

As indication that the governments' quick and expansive policy responses may not represent fundamentally changed priorities, consider that, in the Philippines, business groups are urging the government to spend more to help workers and the vulnerable: by the latter's estimates, P280 billion is needed, which is more than 10 times the P27.1 billion COVID-19 relief announced by the government in March (Department of Finance March 16, 2020). Consider, too, that the Indonesian government announced on June 3, 2020, a stimulus package of US\$ 47.6 billion (Rp 677.2 trillion) to battle COVID-19. Of this, $30 \%$ goes to strengthen social safety nets while $42.6 \%$ goes to micro, small, and medium businesses, labour-intensive businesses, and tax incentives; meanwhile, Bank of Indonesia has injected US\$ 40 billion ( $\mathrm{Rp} 583.5$ trillion) into the economy since the beginning of the year to stabilize the financial market, among other operations (Jakarta Post June 4, 2020).

South Korea's efforts may reflect a reprioritization: the government announced another stimulus package of US \$28.8 billion (35.3 trillion won) on June 3, 2020, bringing the total stimulus package to date of US\$225 billion. Such a reprioritization may align with President Moon Jae-in's plan for an income-led growth model, which had come under fire from businesses, corporations, the conservative opposition in the legislature. Moon's income-led growth has received a new lease in life with COVID-19: the President's handling of the virus has won his Democratic Party and its satellite party a legislative majority of 180 seats, while Moon's approval rating hit $71 \%$ in May (Korea Times May 8, 2020). These circumstances facilitate Moon's pursuit of his income growth model, with a concomitant restructuring of society, politics, and the economy.

\section{Conclusion}

Economic, financial, or even pandemic crises are shocks to countries that illuminate political, social, and economic weaknesses. As governments expend tax dollars, resources, time, and political capital on recovery from the COVID-19 crisis, a key question for the recovery efforts is: should recovery focus on economic growth or a new normal? Recovery to a business-as-usual economic normalcy generally means focusing on an economic rebound that carries with it the burdens of unaddressed fissures, while recovery to a new normal entails reprioritizing society, politics, and economy, usually through committed development of medium- and long-term social policies that gets at weaknesses that were brought to light.

In this paper, we provide evidence of the drawbacks of growth-centric recoveries, and the promises of recovery to a new normal. Specifically, we document the recovery efforts and experiences of three East and Southeast Asian countries-South Korea, Indonesia, and the Philippines - through two crises, the AFC and the GFC, to show that growth-centric focus on recovery to economic normalcy in these countries have contributed to economic fragilities, political instability, and social insecurity. This is an important, given - as we document across the three countries - that it may be tempting to pose economic recovery as a priority that brings widely shared 
benefits. Our examination challenges this assumption and, instead, joins other findings in the literature that show reliance on broad-based growth policies has not only failed to redress the plight of the economically vulnerable, but also impaired the fundamentals of medium- and long-term growth.

We also find that crises may lead to temporary spikes in social policies with extensions of social policy benefits to the informal market and the vulnerable; however, the focus on getting back to business-as-usual means social policies adopted were not well formulated and, therefore, often scuttled following the crises. As a result, even with the expansion of social policies in the countries in this study, levels of cover remain lower than their peers, especially in light of the per capita GDP levels in the nations. As an indication, public expenditure on social policies in South Korea averaged about $10.4 \%$ of GDP in 2015 , compared to the OECD average of $20.5 \%$; it is $2.2 \%$ in the Philippines and $1.1 \%$ in Indonesia for the same period, and this contrasts against $12 \%$ in the lower middle income countries and $8.4 \%$ in lower income countries (OECD 2019; World Databank 2020).

The importance of social policies cannot be overstated: the systematic analyses of survey data show popular preference for social policies over economic growth. This finding is particularly significant for countries in East and Southeast Asia, where economic growth was touted as a predominant priority. In particular, the evidence shows popular preference for social policies drives social trust and cohesion; further, respondents prioritize social policies over economic growth and will protest in support of such priorities.

Our examination reveals a clear lesson for Covid-19 recovery: it needs to target a new normal. Unfortunately, policies to date suggest that, of the three countries in the study, only South Korea appears to be on track for a new normal that reprioritizes society, politics, and economy with social policies that go beyond a stop-gap for the immediate crises, while both Indonesia and the Philippines have adopted policies that are mostly transient. The scope for change, then, remains high.

Funding Research funding in part by the Research Foundation of Korea, NRF-2018S1A3A2075531, Ministry of Education, the Republic of Korea, is gratefully acknowledged.

\section{Compliance with Ethical Standards}

Conflict of interest On behalf of all authors, the corresponding author states that there is no conflict of interest.

\section{Appendix}

See Table 4. 


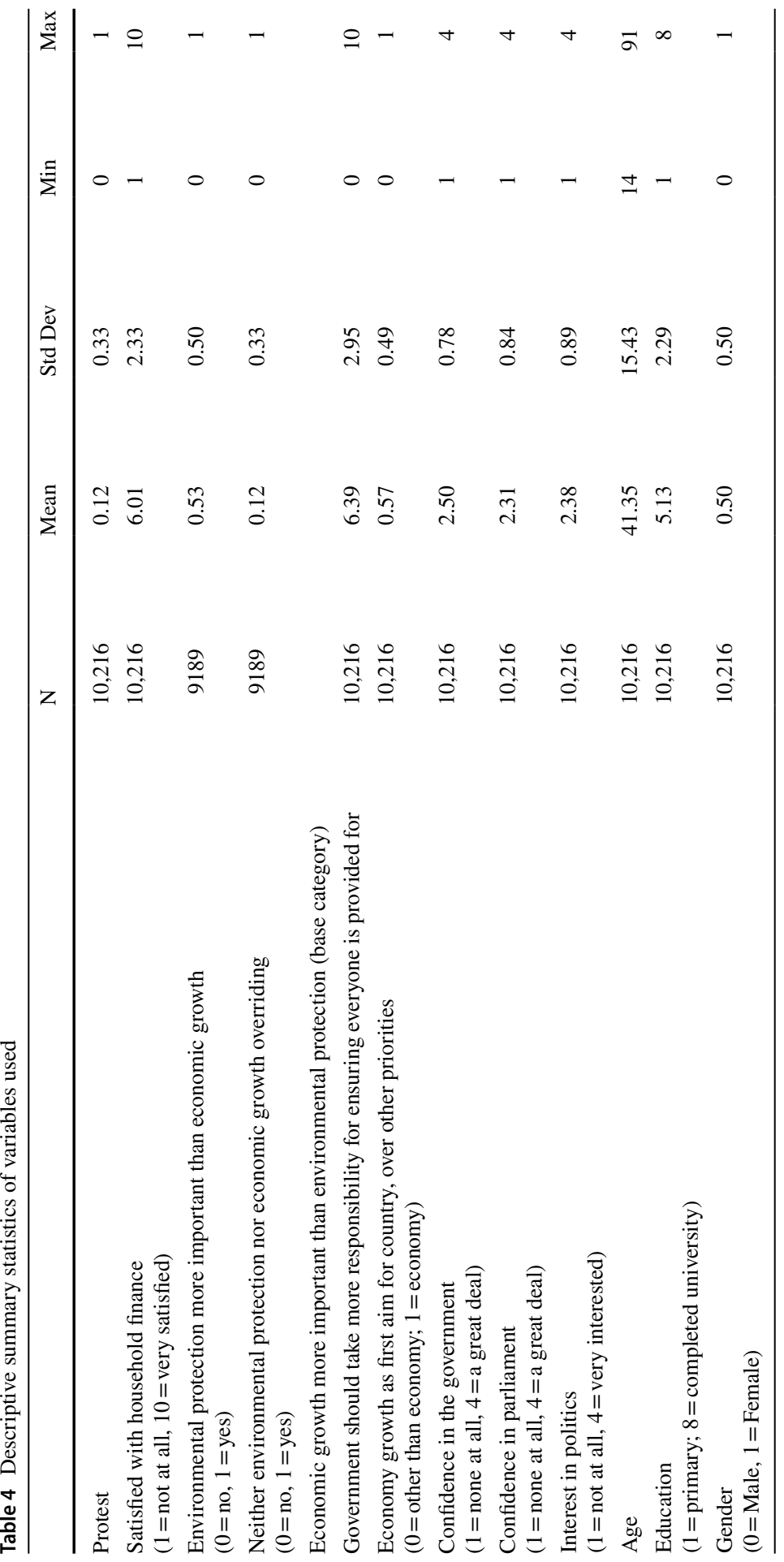




\section{References}

Arulampalam, Wiji, Paul Gregg and Mary Gregory. 2001. Unemployment Scarring. The Economic Journal November 2001: F577-F584

Acosta, Pablo and Rashiel Velarde. 2015. An Update of the Philippine conditional cash transfer's implementation performance. Social Protection Policy note 8. Washington D.C.: World Bank Group

Asian Development Bank (ADB). 2005. Labor Markets in Asia. Manila: ADB

Asian Development Bank (ADB). 2012. Special evaluation Study: Social Protection Strategy 2001. Manila: ADB.

Basso, Gaetano, Mathias Dolls, Werner Eichhorst, Thomas Leoni, and Andreas Peichl, T. 2011. The Effects of the Recent Economic Crisis on Social Protection and Labour Market Arrangements Across Socio-Economic Groups. IZA Discussion Paper No. 6080.

Basso, Gaetano, Mathias Dolls, Werner Eichhorst, Thomas Leoni and Andreas Peichl, T. 2012. The Effects of the Recent Economic Crisis on Social Protection and Labour Market Arrangements Across Socio-Economic Groups. IZA Discussion Paper No. 6080.

Bernanke, Ben. 2009. Welcome Address: Asia and the Global Financial Crisis. Asia Economic Policy Conference, Federal Reserve bank of San Francisco

Bersales, Lisa and Vivian Ilarina. 2019. Measuring the contribution of the informal sector to the Philipine Economy: Current Practices and Challenges. Paper presented at the 7th IMF Statistical Forum: Measuring the Informal Economy.

Birdsall, Nancy. 2011. The Global Financial Crisis: The Beginning of the End of the 'Development' Agenda? In New Ideas on Development After the Financial Crisis, ed. Nancy Birdsall and Francis Fukuyama. Baltimore: Johns Hopkins Press

Brandt, Martina, and Karsten Hank. 2014. Scars that will not Disappear: Long-term Associations Between Early and Later life Unemployment under Different Welfare Regimes. Journal of Social Policy 43: 727-743.

Brown, David S., and Wendy Hunter. 1999. Democracy and Social Spending in Latin America, 1980-92. American Political Science Review 93 (4): 779-790.

Choi, Nankyung. 2004. Local Elections and Party Politics in Post-Reformasi Indonesia: A View from Yogyakarta. Contemporary Southeast Asia: A Journal of International and Strategic Affairs 26: 280-301.

CNBC. South Korea announces $\$ 29$ billion third stimulus budget to fight coronavirus crisis. https://www. cnbc.com/2020/06/03/south-korea-announces-29-billion-third-stimulus-budget-to-fight-virus.html. Accessed 18 June 2020.

Collier, David. 1993. The Comparative Method. In Political Science: The State of the Discipline II, ed. Ada Finiter. Washington D.C.: American Political Science Association.

Cook, Karen S. 2005. Networks, Norms, and Trust: The Social Psychology of Social Capital* 2004 Cooley Mead Award Address. Social Psychology Quarterly 68 (1): 4-14.

Cooke, Fang, and Yumei Jiang. 2017. The Growth of Non-standard Employment in Japan and South Korea: The Role of Institutional Actors and Impact on Workers and the Labour Market. Asia Pacific Journal of Human Resources 55: 155-176.

Coronel, Sheila S. 2007. The Philippines in 2006: Democracy and Its Discontents. Asian Survey 47 (1): $175-182$.

Das, Dilip. 2012. How did the Asian Economy Cope with the Global Financial Crisis and Recession? A Revaluation and Review. Asia Pacific Business Review 18: 7-25.

de Haan, Arjan. 2014. The Rise of Social Protection in Development: Progress, Pitfalls and Politics. European Journal of Development Research 26: 311-321.

Dutt, Amitava. 2013. The Global Financial Crisis: Views from Asia. Development and Change 44: $175-187$.

Eichhorst, Werner, Paul Marx, and Caroline Wehner. 2017. Labor Market Reforms in Europe: Towards More Flexicure Labor Markets? Journal for Labour Market Research 51 (1): 3.

Fischer, Stanley. 2001. Asia and the IMF-Remarks by Stanley Fischer. Institute of Policy Studies, Singapore https://www.imf.org/en/News/Articles/2015/09/28/04/53/sp060101. Accessed 12 June 2020.

Gandhi, Jennifer. 2008. Dictatorial Institutions and their Impact on Economic Growth. European Journal of Sociology 49 (1): 27.

Geddes, Barbara, Erica Frantz, and Joseph Wright. 2014. Military Rule. Annual Review of Political Science 17: 147-162. 
Gentilini, Ugo, Mohamed Almenfi and Ian Orton. 2020. Social Protection and Jobs Responses to COVID19: A Real-Time Review of Country Measures. A living paper, version June 12, 2020. World bank open knowledge repository, https://openknowledge.worldbank.org/handle/10986/33635. Accessed 20 June 2020.

Gentilini, Ugo, Mohamed Almenfi and Ian Orton. 2020. Social Protection and Jobs Responses to COVID-19: A Real-Time Review of Country Measures. A living paper, version March 27, 2020. World bank open knowledge repository. https://openknowledge.worldbank.org/handle/10986/33635 . Accessed 20 June 2020

Global Economy. 2020. Business and Economic Data. https://www.theglobaleconomy.com/. Accessed 2 May 2020

Gomez, Brad T., and J. Matthew Wilson. 2006. Cognitive Heterogeneity and Economic Voting: A Comparative Analysis of Four Democratic Electorates. American Journal of Political Science 50 (1): 127-145.

Haggard, Stephan, and Robert Kaufman. 2008. Democracy, Development and Welfare States: Latin America, East Asia, and Eastern Europe. Princeton: Princeton University Press.

Haggard, Stephan. 2005. Globalization, Democracy, and the Evolution of Social Contracts in East Asia. Taiwan Journal of Democracy 1: 21-48.

Handayani, Sri Wening. 2016. Overview. In Social Protection for Informal Workers in Asia, ed. Sri Wening Handayani. Manila, The Asian Development Bank: 425.

Harimurti, Pandu, Eko Pambudi, Anna Pigazzini, and Ajay Tandon. 2013. The Nuts \& Bolts of Jamkesmas, Indonesia's Government-Financed Health Coverage Program for the Poor and NearPoor. UNICO Studies Series No. 8. Washington DC: World Bank

Headey, Bruce, Robert Goodin, Rudd Muffels, and Henk-Jan. Dirven. 2000. Is There a Trade-Off Between Economic Efficiency and a Generous Welfare State? A Comparison of Best Cases of 'The Three Worlds of Welfare Capitalism. Social Indicators Research 50: 115-157.

Human Development Report. 1999. New York: Oxford University Press, for the United Nations Development Programme

Human Development Report, Philippines. 2005. UN Development Programme

International Labour Organization (ILO). 2020a. ILO Stat database. Geneva: ILO https://ilostat.ilo. org/data/. Accessed 20 June 2020

International Labour Organization. 2020b. World Social Protection Report 2017-2019. Geneva: ILO.

International Labour Organization. 2020c. 2030 Development agenda: ILO Focus targets. Geneva: ILO. https://www.ilo.org/global/topics/sdg-2030/targets/lang--en/index.htm. Accessed 15 May 2020 .

James, William, Donghyun Park, Shikha Jha, Juthathip Jongwanich, Akiko Terada-Hagiwara, and Lea Sumulong. 2008. The US Financial Crisis, Global Financial Turmoil, and Developing Asia: Is the Era of High Growth at an End? Asian Development Bank (ADB) Economics Working Papers. Manila: ADB

Jakarta Post. Indonesia unveils bigger stimulus worth $\$ 47.6$ billion to fight coronavirus impacts. June 4, 2020. https://www.thejakartapost.com/news/2020/06/04/indonesia-unveils-bigger-stimulusworth-47-6-billion-to-fight-coronavirus-impacts.html. Accessed 15 June 2020.

Justino, Patricia, and Bruno Martorano. 2019. Redistributive Preferences and Protests in Latin America. Journal of Conflict Resolution 62: 2128-2154.

Kim, Eunju, and Jayoung Yoo. 2015. Conditional Cast Transfer in the Philippines. Asia and the Pacific Policy Studies 2: 75-89.

Korea Times. Moon's approval rating exceeds $70 \%$ https://www.koreatimes.co.kr/www/natio n/2020/05/356_289208.html. Accessed 2 June 2020.

Kwon, Huck-ju. 2005. Transforming the Developmental Welfare State in East Asia. Development and Change 36: 477-497.

Kwon, Jene and Jung Mo Kang. 2011. The East Asian Model of Economic Development. AsianPacific Economic Literature: 116-130.

Kwak, YoonKyung. 2011. South Korea's experience in Social Protection. International Policy Centre for Inclusive Growth, https://www.slideshare.net/ipcig/south-koreas-experience-in-social-prote ction. Accessed 20 May 2020.

Kwon, Soonman, and Ian Holliday. 2007. The Korean Welfare State: A Paradox of Expansion in an Era of Globalisation and Economic Crisis. International Journal of Social Welfare 16: 242-248.

Landler, Mark. October 23, 1999. In Indonesia, All Eyes on Economy. The New York Times

https://www.nytimes.com/1999/10/23/world/in-indonesia-all-eyes-on-economy.html 
Lamberte, Mario. 1986. Social Adequacy and Economic Effects of Social Security: The Philippine Case. ASEAN Economic Bulletin 3: 92-123.

Lee, Sunju. 2015. Social Security System of South Korea. InterAmerican Development Bank (IDB) Technical Note IDB-TN-872. Washington D.C.: IDB

Levy, Jack S. 2008. Case Studies: Types, Designs, and Logics of Inference. Conflict Management and Peace Science 25 (1): 1-18.

Liddle, William. 2001. Indonesia in 2000: A Shaky Start for Democracy. Asian Survey 41: 208-220.

Malley, Michael. 2002. Indonesia in 2001: Restoring Stability in Jakarta. Asian Survey 42: 124-132.

Mavromaras, Kostas, Peter Sloane, and Zhang Wei. 2015. The scarring effects of unemployment, low pay and skills under-utilization in Australia compared. Journal of Applied Economics 47

Mill, J.S. 1875. System of Logic. New York: Harper \& Brothers.

Nasution, Anwar. 2016. Government Decentralization Program in Indonesia. Asian Development Bank Institute Working Paper Series No. 601

OECD. 2000. Pushing Ahead with Reform in Korea: Labour market and social safety-net policies. Paris: OECD.

OECD. 2017. A Decade of Social Protection Development in Selected Asian Countries. Paris: OECD.

OECD. 2018a. Towards Better Social and Employment Security in Korea. Connecting People with Jobs. Paris: OECD

OECD. 2018b. OECD Economic Surveys: Indonesia, 2018. Paris: OECD.

OECD. 2020. OECD Statistics. https://stats.oecd.org/ <last accessed June 1, 2020>

Orbeta, Aniceto and Vicente Paqueo. 2016. Pantawid Pamilya Pilipino Program: Boon or Bane?. Philippine Institute for Development Studies Discussion Paper Series No. 2016-56

Pempel, T.J. 2015. Two crises, two outcomes. In Two Crises, Different Outcomes: East Asia and Global Finance. Pempel, T.J., \& Keiichi Tsunekawa, eds. Ithaca; London: Cornell University Press

Philippines Department of Finance. 16 March 2020. Gov't economic team rolls out P27.1 B package vs COVID-19 pandemic. https://www.dof.gov.ph/govt-economic-team-rolls-out-p27-1-b-packa ge-vs-covid-19-pandemic/. 4 May 2020.

Philippines News Agency. House to review SAP implementation. June 15, 2020. Accessed 25 June 2020.

Philippines Official Gazette. June 18, 1954. Republic Act No. 1161: The Social Security Act of 1954. https://www.officialgazette.gov.ph/1954/06/18/republic-act-no-1161/

Philippines Official Gazette. September 27, 1994. Statement: President Fidel V. Ramos at the Social Reform Summit. https://www.officialgazette.gov.ph/1994/09/27/statement-president-fidel -v-ramos-at-the-social-reform-summit/

Philippines Official Gazette. February 15, 1988. Message of the President Corazon Aquino on the Community Employment and Development Plan. https://www.officialgazette.gov.ph/1988/02/15/ message-of-president-corazon-aquino-on-the-community-employment-and-development-progr $\mathrm{am} /$

Pisani, E., Olivier Kok, and K. Nugroho. 2017. Indonesia's Road to Universal Health Coverage: A Political Journey. Health Policy and Planning 32: 267-276.

Przeworski, Adam, and Henry Teune. 1970. The Logic of Comparative Social Inquiry. New York: John WIley and Sons.

Putnam, Robert D. 1993. Making Democracy Work: Civic Traditions in Modern Italy. New Jersey: Princeton University Press.

Radelet, Steven and Jeffrey Sachs. 1998. The Onset of the East Asian Financial Crisis. NBER Working Paper No. 6680. August 1998

Ratigan, Kerry. 2017. Disaggregating the Developing Welfare State: Provincial Social Policy Regimes in China. World Development 98: 467-484.

Reich, Gary M. 1999. Coordinating Restraint: Democratization, Fiscal Policy and Money Creation in Latin America. Political Research Quarterly 52 (4):729-751.

Reinhart, Carmen M., and Kenneth S. Rogoff. 2004. The Modern History of Exchange Rate Arrangements: A Reinterpretation. Quarterly Journal of economics 119 (1): 1-48.

Romero, Segundo. 1998. The Philippines in 1997: Weathering Political and Economic Turmoil. Asian Survey 38: 196-202.

Rothstein, Bo., and Eric M. Uslaner. 2005. All for All: Equality, Corruption, and Social Trust. World Politics 58 (1): 41-72. 
Sam, Hickey, Tom Lavers, Miguel Niño-Zarazúa, and Jeremy Seekings. 2018. The negotiated politics of social protection in sub-Saharan Africa. Finland, UNU-WIDER: Helsinki.

Shrestha, Prakash Kumar. 2013. Economic Development In South And East Asia: Empirical Examination Of East Asian Development Model. Asia-Pacific Development Journal 20 (2): 1-28.

Statistics Indonesia. 2020. Statistical Yearbook of Indonesia (Statistik Indonesia). Jakarta: BPS-Statistics Indonesia. https://www.bps.go.id. Accessed 3 June 2020.

Statistics-Indonesia. 2010. Indonesia Population Census, 2010. Jakarta: BPS-Statistics Indonesia.

Steindel, Charles. 2009. Implications of the Financial Crisis for Potential Growth: Past, Present, and Future. Federal Reserve Bank of New York Staff Report No. 408.

Stiglitz, Joseph. 2016. Inequality and Economic Growth. The Political Quarterly 86: 134-155.

Stiglitz, Joseph. 2000. What I learned at the World Economic Crisis. New Republic April 17, 2020

Sumarto, Sudarno. 2006. Policy Brief 5: Social Safety Nets, Indonesia. Overseas Development Institute.

Sumarto, Mulyadi. 2017. Welfare Regime Change in Developing Countries: Evidence from Indonesia. Social Policy and Administration 51: 940-959.

Suryahadi, Asep, Vita Febriany and Athia Yumna. 2014. Expanding Social Security in Indonesia: The processes and challenges. United Nations Research Institute for Social Development Working Paper 2014-14.

World Bank. 1993. The making of the East Asia Miracle. Washington, D.C.: World Bank Group.

World Bank. 2020. World Bank Databank. Washington D.C.: World Bank. Accessed 20 May 2020

World Bank. 2020. The Philippines: New Project to help provide Individual Land titles to 750,000 Agrarian Reform Beneficiaries. World Bank Press Release June 26, 2020 https://www.world bank.org/en/news/press-release/2020/06/26/philippines-new-project-to-help-provide-individual -land-titles-to-750000-agrarian-reform-beneficiaries. Accessed 22 Sept 2020.

World Values Survey 1981-2014 Longitudinal Aggregate V.20150418. World Values Survey Association. Aggregate File Producer: JDSystems, Madrid SPAIN. https://www.worldvaluessurvey.org

Yap, O. Fiona. 2006. Agenda Control, Intraparty Conflict, and Government Spending in Asia: Evidence from South Korea and Taiwan. Journal of East Asian Studies 6 (1): 35.

Yap, O. Fiona. 2019. How Political Trust Matters in Emergent Democracies: Evidence from East and Southeast Asia. Journal of Public Policy 39 (2): 295-328.

Yap, O. Fiona. 2020, forthcoming. What's Game-theory got to do with it? A Democratization Model of East and Southeast Asia. Asian Survey

Publisher's Note Springer Nature remains neutral with regard to jurisdictional claims in published maps and institutional affiliations. 